University of Nebraska - Lincoln

DigitalCommons@University of Nebraska - Lincoln

Faculty Publications: Department of Entomology

$4-1-2008$

\title{
Levels of Tolerance, Antibiosis, and Antixenosis Among Resistant Buffalograsses and Zoysiagrasses
}

Thomas E. Eickhoff

Monsanto Company, Monmouth, IL

Tiffany Heng-Moss

University of Nebraska-Lincoln, thengmoss2@unl.edu

Frederick P. Baxendale

University of Nebraska-Lincoln, fbaxendale1@unl.edu

John E. Foster

University of Nebraska-Lincoln, john.foster@unl.edu

Follow this and additional works at: https://digitalcommons.unl.edu/entomologyfacpub

Part of the Entomology Commons

Eickhoff, Thomas E.; Heng-Moss, Tiffany; Baxendale, Frederick P.; and Foster, John E., "Levels of Tolerance, Antibiosis, and Antixenosis Among Resistant Buffalograsses and Zoysiagrasses" (2008). Faculty Publications: Department of Entomology. 123.

https://digitalcommons.unl.edu/entomologyfacpub/123

This Article is brought to you for free and open access by the Entomology, Department of at DigitalCommons@University of Nebraska - Lincoln. It has been accepted for inclusion in Faculty Publications: Department of Entomology by an authorized administrator of DigitalCommons@University of Nebraska - Lincoln. 


\title{
Levels of Tolerance, Antibiosis, and Antixenosis Among Resistant Buffalograsses and Zoysiagrasses
}

\author{
THOMAS E. EICKHOFF,${ }^{1,2}$ TIFFANY M. HENG-MOSS,${ }^{3}$ FREDERICK P. BAXENDALE, ${ }^{3}$ \\ AND JOHN E. FOSTER ${ }^{3}$
}

\begin{abstract}
J. Econ. Entomol. 101(2): 533-540 (2008)
ABSTRACT The western chinch bug, Blissus occiduus Barber, has been documented as one of the most serious pests of buffalograss, Buchloë dactyloides (Nuttall) Engelmann, and zoysiagrass, Zoysia japonica Steudel, grown for turf in midwestern states. Resistance to the western chinch bug has been identified in both buffalograsses and zoysiagrasses. Choice and no-choice studies were conducted to determine the categories (antibiosis, antixenosis, and tolerance) of three resistant buffalograsses (PX3-5-1', 196', and 184') and three resistant zoysiagrasses (El Toro, Emerald, and Zorro). Antibiosis studies found no significant differences in survival, nymphal development, or fecundity among the resistant and susceptible buffalograsses or zoysiagrasses, indicating that antibiosis is not an important factor in the resistance. Based on chinch bug damage ratings, 184, 196, and PX3-5-1 have comparable levels of tolerance to the known tolerant buffalograss 'Prestige', and Zorro was the most tolerant zoysiagrass. Choice studies indicated the presence of antixenosis in the buffalograss selection 196 and the zoysiagrass Emerald.
\end{abstract}

KEY WORDS plant resistance, chinch bug, turfgrass, Blissus occiduus

The western chinch bug, Blissus occiduus Barber, is an important insect pest of buffalograss, Buchloë dactyloides (Nuttall) Engelmann, and zoysiagrass, Zoysia japonica Steudel (Baxendale et al. 1999, Eickhoff et al. 2004). Although insecticides effectively control this sap-feeding insect, plants with resistance offer an attractive alternative pest management approach because it provides an efficient, economical and environmentally responsible approach for effectively managing pests and diseases. Buffalograsses and zoysiagrasses with resistance to $B$. occiduus have been identified (Heng-Moss et al. 2002, Gulsen et al. 2004, Eickhoff et al. 2006), but only limited information is available on the specific categories (antibiosis, antixenosis, and tolerance) of resistance present in these grasses. Knowledge of the categories of resistance in these warm-season grasses is critical for preserving these resistance traits and facilitating development of appropriate resistance management plans for the western chinch bug.

Numerous studies have identified differing levels of resistance to insects among the major turfgrass species grown in the United States (Baker et al. 1981; Reinert 1982; Reinert and Busey 2001; Ahmad et al. 1986; Johnson-Cicalese et al. 1989, 1998; Quisenberry 1990; Braman et al. 1994; Heng-Moss et al. 2002; Rangasamy et al. 2006), and several researchers have character-

\footnotetext{
${ }^{1}$ Monsanto Company, Monmouth, IL 61462.

${ }^{2}$ Corresponding author, e-mail: thomas.e.eickhoff@monsanto.com.

${ }^{3}$ Department of Entomology, University of Nebraska, Lincoln, NE 68583
}

ized the resistance present in these grasses (Smith 1989, Heng-Moss et al. 2003, Rangasamy et al. 2006). Among turfgrasses identified as resistant, suggested resistant mechanisms have included increased plant tolerance due to modifications in plant proteins and increased oxidative enzyme activity, altered resource reallocation and greater rhizome number, turf density and vigor; antibiosis factors involving chemical and morphological plant defenses that result in insect mortality, reduced oviposition and an extended life cycles; and antixenosis factors such as pubescence, surface waxes, and leaf size and width that adversely affect the behavior of the insect (Baker et al. 1981; Reinert 1982; Johnson-Cicalese et al. 1989, 1998; Smith et al. 1994; Heng-Moss et al. 2004, 2006) .

Greenhouse experiments conducted to assess the resistance of selected buffalograsses and zoysiagrasses to B. occiduus identified the buffalograsses ' 196 ', ' $184^{\prime}$, and 'PX3-5-1', and the zoysiagrasses 'El Toro', 'Emerald', and 'Zorro' as resistant to B. occiduus (Gulsen et al. 2004, Eickhoff et al. 2006). Although these buffalograsses and zoysiagrasses have documented chinch bug resistance, studies were needed to identify the categories of resistance. Identifying the categories and levels of antibiosis, antixenosis, and tolerance will contribute to our understanding of the mechanisms underlying the resistance, and potentially expedite the germplasm screening process. The objectives of this research were to characterize the categories of $B$. occiduus resistance among selected buffalograsses and zoysiagrasses to enhance our understanding of the underlying resistant mechanisms. 


\section{Materials and Methods}

Choice and no-choice experiments were conducted to characterize the relative levels of tolerance, antibiosis, and antixenosis among three resistant buffalograsses and three resistant zoysiagrasses by using methods described by Eickhoff et al. (2006).

\section{Tolerance Studies}

Buffalograss Tolerance Studies 1 and 2. Two separate studies were conducted to document levels of tolerance among the resistant buffalograsses: 184, 196, and PX3-5-1. All buffalograsses were compared with the known resistant and susceptible buffalograsses, 'Prestige' and ' 378 ', respectively (Heng-Moss et al. 2003). Sod plugs (10.6 cm in diameter by $8 \mathrm{~cm}$ in depth) of Prestige and 378 were extracted from research plots at the John Seaton Anderson Turfgrass and Ornamental Research Facility (JSA Research Facility), University of Nebraska Agricultural Research and Development Center near Mead, NE. Vegetative clones of the buffalograsses PX3-5-1, 184, and 196 were obtained from a collection located at Utah State University, Logan, UT. All grasses were vegetatively established in the greenhouse in 35 - by $50-\mathrm{cm}$ flats and provided the vegetative plant material for experiments.

Before initiation of experiments, turfgrasses were vegetatively propagated by planting individual stolons of each grass in 'SC-10 Super Cell' single cell conetainers $(3.8 \mathrm{~cm}$ in diameter by $21 \mathrm{~cm}$ in depth) (Stuewe \& Sons, Inc., Corvallis, OR) containing a potting mixture of sand-soil-peat-perlite in a 2:1:3:3 ratio. Cone-tainers were placed in 7 by $14 \mathrm{U}$ cone-tainer trays (Stuewe \& Sons, Inc.). Plants were irrigated as needed, fertilized weekly with a soluble $(20 \mathrm{~N}-10 \mathrm{P}-$ $20 \mathrm{~K}$ ) fertilizer, and they were maintained under 400-W high-intensity discharge lamps, with a photoperiod of 16:8 (L:D) h. Grasses were trimmed to the soil surface $\approx 2 \mathrm{wk}$ before initiation of experiments to ensure all plant material was approximately the same age at the onset of the experiment.

Buffalograss tolerance studies 1 and 2 were conducted under greenhouse conditions using B. occiduus collected from buffalograss research plots at the JSA Research Facility by vacuuming the soil surface with a modified ECHO Shred 'N Vac (model 2400, ECHO Incorporated, Lake Zurich, IL). Chinch bugs were held under laboratory conditions $\left(26 \pm 3^{\circ} \mathrm{C}\right.$ and a photoperiod of 16:8 [L:D] h), and they were preconditioned by starving for $24 \mathrm{~h}$ before initiation of the experiment. In total, 10 fourth and fifth (determined according to Baxendale et al. 1999) instars of chinch bugs (sex undetermined) were collected with an aspirator and placed on plants in cone-tainers fitted with tubular Plexiglas cages $(4 \mathrm{~cm}$ in diameter by $30 \mathrm{~cm}$ in height). Cage tops were covered with organdy fabric.

The experimental design for both studies was a completely randomized design with six replications for study 1 , and 10 replications for study 2 . Each study had three replications of uninfested controls. Both studies were conducted using second-generation chinch bugs (Baxendale et al. 1999). Studies 1 and 2 were conducted from 30 September to 25 October 2004 and from 4 to 28 October 2005, respectively.

The susceptibility of the turfgrasses to $B$. occiduus feeding was measured by visually rating plants for chinch bug damage. Damage ratings were based on a $1-5$ scale, where $1, \leq 10 \% ; 2,11-30 \% ; 3,31-50 \% ; 4$, $51-70 \%$ of leaf area with reddish or yellowing discoloration, respectively; and $5, \geq 71 \%$ or more of leaf area with severe discoloration or dead tissue (Heng-Moss et al. 2002). When the mean chinch bug damage rating of the B. occiduus-susceptible grass (378) reached 4.0 or higher, the contents (soil and grass) of each conetainer were placed in a Berlese funnel (Southwood 1978) for 48 h. Extracted chinch bugs were collected in $70 \%$ ethyl alcohol and counted.

Zoysiagrass Tolerance Studies 1 and 2. Two studies were conducted to document levels of tolerance among the resistant zoysiagrasses: El Toro, Emerald, and Zorro. All grasses were compared with the known susceptible zoysiagrass 'Meyer' (Eickhoff et al. 2006). The zoysiagrasses: Emerald, El Toro, and Meyer were acquired from Turfgrass America (Cleveland, TX). The zoysiagrass Zorro was obtained from M. C. Engelke at Texas A\&M University (Dallas, TX). The procedures in these studies followed those previously described for buffalograss tolerance studies 1 and 2 .

Statistical Analyses. Mixed model analyses (PROC MIXED, SAS Institute 2002) were conducted to detect differences in chinch bug damage ratings. When appropriate, means were separated using Fisher least significant difference (LSD) procedure.

\section{Antibiosis Studies}

Six studies (four with buffalograsses and two with zoysiagrasses) were conducted to document levels of antibiosis to B. occiduus. Fecundity, nymphal development, and chinch bug survival were used to assess the levels of antibiosis among the resistant buffalograsses (184, 196, and PX3-5-1) and zoysiagrasses (El Toro, Emerald, and Zorro). The chinch bug-susceptible 378 and chinch bug-resistant Prestige were included in the buffalograss antibiosis studies as controls. The chinch bug-susceptible Meyer was used as a control in the zoysiagrass studies.

Buffalograss Antibiosis Studies 1 and 2. Two separate studies were carried out to assess the long-term antibiotic effects of the resistant buffalograsses on chinch bug fecundity. The buffalograsses used in these studies were acquired from the previously mentioned sources, and they were vegetatively propagated in cone-tainers and maintained as described previously. For these studies, first instar chinch bugs were collected from a buffalograss stand on the University of Nebraska campus in Lincoln, NE. Before initiation of these experiments, chinch bugs were maintained on cone-tainers containing each of the buffalograsses under investigation until they reached adulthood. At the start of each experiment, one female and one male chinch bug were introduced on each of the five buf- 
falograsses in individual cone-tainers. A tubular, Plexiglas cage (4 cm in diameter by $30 \mathrm{~cm}$ in height) provided a barrier to prevent chinch bug escape.

The experimental design was a completely randomized design with eight replications per study. Experiments were terminated $36 \mathrm{~d}$ after the adults were introduced, and total number of chinch bug offspring was recorded.

Buffalograss Antibiosis Studies 3 and 4. Two additional experiments were conducted to detect antibiotic effects of resistant buffalograsses on nymphal development and chinch bug survival. Turfgrasses were obtained, established and maintained as previously described. In total, 10 newly hatched first instars of chinch bugs were collected from a buffalograss stand on the University of Nebraska campus in Lincoln, NE, and introduced on each cone-tainer of each of the five buffalograsses.

The experimental design for antibiosis studies 3 and 4 was a completely randomized design with eight replications per study. At the conclusion of these studies, the contents of each cone-tainer (soil and grass) were examined for chinch bug presence, and all surviving chinch bugs were counted and age classified according to Baxendale et al. (1999). Chinch bug survival and development stages were recorded at 37 and $36 \mathrm{~d}$ after chinch bug introduction for studies 3 and 4 , respectively. Study three was conducted from 23 May to 27 June, 2006, and study four was conducted from 26 May to 29 June 2006.

Zoysiagrass Antibiosis Studies 1 and 2. Insufficient numbers of adult chinch bugs preconditioned on the appropriate zoysiagrasses were available to conduct fecundity studies for the resistant zoysiagrasses. However, two experiments were conducted to detect antibiotic effects of resistant zoysiagrasses, El Toro, Emerald, and Zorro on nymphal development and chinch bug survival. The resistant zoysiagrasses were compared with the susceptible zoysiagrass Meyer.

All grasses used in these studies were obtained, established and maintained as described previously, and the experimental procedures were the same as described for buffalograss antibiosis studies 3 and 4 .

Statistical Analyses. Mixed model analyses (PROC MIXED, SAS Institute 2002) were conducted to detect differences in the number of offspring produced, nymphal development, and chinch bug survival (Littell et al. 1996). When appropriate, means were separated using Fisher LSD procedure.

\section{Antixenosis Studies}

In total, four choice studies (two with buffalograss and two with zoysiagrass) were conducted under growth chamber conditions to document chinch bug preference for selected buffalograsses and zoysiagrasses.

Buffalograss Antixenosis Studies. Two separate studies were conducted to document $B$. occiduus preference for the selected buffalograsses (184, 196, and PX3-5-1). The buffalograsses NE 86-120 and Prestige were included as controls because NE $86-120$ has been documented to be highly preferred by B. occiduus, and Prestige has been shown to exhibit low levels of antixenosis (Heng-Moss et al. 2003).

Chinch bugs were collected from buffalograss research plots at the JSA Research Facility near Mead, $\mathrm{NE}$, as described previously. Chinch bugs were held under laboratory conditions $\left(26 \pm 3^{\circ} \mathrm{C}\right.$ and a photoperiod of $16: 8[\mathrm{~L}: \mathrm{D}] \mathrm{h}$ ), and they were preconditioned by starving them for $24 \mathrm{~h}$ before the initiation of the experiment.

All grasses were obtained, established, and maintained in the greenhouse as described previously. Individual plants were removed from cone-tainers, placed in vials of water and sealed with molten $(63 \pm$ $2^{\circ} \mathrm{C}$ ) paraffin wax (Gulf Wax, Royal Oaks Sales, Inc., Roswell, GA). Vials with grasses were randomly inserted into $1.7-\mathrm{cm}$-diameter holes drilled in circular test arenas (16 cm in diameter by $8 \mathrm{~cm}$ in depth). A $2-\mathrm{cm}$ band of petroleum jelly was applied to the top portion of each arena to prevent chinch bug escape.

Twenty-five fourth and fifth instars of chinch bugs were released in the center of each arena. The number of chinch bugs on each grass plant was visually documented at $1,2,4,8,24,48$, and $72 \mathrm{~h}$ after chinch bug introduction.

All studies were conducted in a growth chamber maintained at $28 \pm 2^{\circ} \mathrm{C}$ under 24 -h lighting. The experimental design for each study was a randomized complete block design with 10 replications.

Zoysiagrass Antixenosis Studies 1 and 2. Two additional studies were conducted using three chinch bugresistant zoysiagrasses (El Toro, Emerald, and Zorro) to document B. occiduus preference for these selected zoysiagrasses. Again, the resistant zoysiagrasses were compared with the known susceptible zoysiagrass Meyer. All grasses used in these studies were obtained, established, and maintained as described previously, and the experimental procedures were the same as described for buffalograss antixenosis studies 1 and 2 .

Statistical Analyses. Mixed model analyses (PROC MIXED, SAS Institute 2002) were conducted to identify differences in chinch bug preference among the evaluated grasses. The residuals from the mixed model analyses were inspected to check model assumptions of normality and constant variance. No significant violations of these assumptions were detected. When appropriate, means were separated using Fisher LSD procedure.

\section{Results and Discussion}

\section{Tolerance Studies}

Buffalograss Tolerance Studies 1 and 2. Significant differences (study 1: $F=11.0 ; \mathrm{df}=9,35 ; P=0.0001$; study $2: F=10.2 ; \mathrm{df}=9,54 ; P=0.0001$ ) in chinch bug damage ratings were detected among the five buffalograsses (Table 1). Buffalograss 378 had significantly higher damage ratings of 4.5 and 4.0 than the other genotypes in studies 1 and 2 , respectively. These results demonstrate that 378 is highly susceptible to $B$. occiduus feeding, which supports the findings of Heng- 
Table 1. Comparison of $B$. occiduus damage ratings between control and infested buffalograsses (studies 1 and 2)

\begin{tabular}{lccccc}
\hline \hline \multirow{2}{*}{ Buffalograss } & \multicolumn{3}{c}{ Chinch bug damage ratings ${ }^{a}$} \\
\cline { 2 - 3 } \cline { 5 - 6 } & \multicolumn{2}{c}{ Study 1} & & \multicolumn{2}{c}{ Study 2} \\
\cline { 2 - 3 } \cline { 5 - 6 } & Infested & Control & & Infested & Control \\
\hline $378^{b}$ & $4.5 \mathrm{a}$ & $1.0 \mathrm{c}$ & & $4.0 \mathrm{a}$ & $1.0 \mathrm{~d}$ \\
184 & $3.0 \mathrm{~b}$ & $1.0 \mathrm{c}$ & & $2.5 \mathrm{bc}$ & $1.0 \mathrm{~d}$ \\
196 & $2.8 \mathrm{~b}$ & $1.0 \mathrm{c}$ & & $2.8 \mathrm{~b}$ & $1.0 \mathrm{~d}$ \\
Prestige $^{c}$ & $2.7 \mathrm{~b}$ & $1.0 \mathrm{c}$ & & $2.4 \mathrm{bc}$ & $1.0 \mathrm{~d}$ \\
PX3-5-1 & $2.3 \mathrm{~b}$ & $1.0 \mathrm{c}$ & & $2.0 \mathrm{~cd}$ & $1.0 \mathrm{~d}$ \\
\hline
\end{tabular}

Means within columns and rows (within the same study) followed by the same letter are not significantly different $(P>0.05$; LSD test).

${ }^{a}$ Chinch damage ratings were based on a $1-5$ scale, where $1, \leq 10 \%$ and $5, \geq 71 \%$ damage (Heng-Moss et al. 2002).

${ }^{b}$ Susceptible buffalograss (Heng-Moss et al. 2002)

${ }^{c}$ Resistant buffalograss (Heng-Moss et al. 2002).

Moss et al. (2002). All grasses tested had significantly higher damage ratings than their respective untreated controls in both studies except for PX3-5-1 in study 2 . However, none of the test grasses were significantly different from the known resistant buffalograss Prestige.

The results of these studies indicate the buffalograsses 184, 196, and PX3-5-1 have comparable levels of tolerance to those of Prestige (NE91-118) as documented by Heng-Moss et al. (2003). It is important to note that Heng-Moss et al. (2003) failed to find significant differences in damage ratings between the untreated control and Prestige, suggesting that Prestige was highly tolerant. These studies found significant differences between the resistant buffalograss and the untreated controls. This inconsistency is likely due to different infestation levels. Heng-Moss et al. (2003) introduced six chinch bugs per plant whereas 10 chinch bugs were introduced in these studies. These experiments confirm that even a tolerant grass can be damaged by chinch bug feeding at a high enough infestation levels.

Zoysiagrass Tolerance Studies 1 and 2. Significant differences (study $1: F=14.3$; df $=7,28 ; P=0.0001$; study $2: F=8.3 ; \mathrm{df}=7,44 ; P=0.0001)$ in chinch bug damage ratings were detected among the four zoysiagrass cultivars (Table 2). Meyer was the most susceptible zoysiagrass tested with damage ratings of 3.7 and 3.3 in studies 1 and 2 , respectively. There were no

Table 2. Comparison of $\boldsymbol{B}$. occiduus damage ratings between control and infested zoysiagrasses (studies 1 and 2)

\begin{tabular}{llclll}
\hline \multirow{2}{*}{ Zoysiagrass } & \multicolumn{3}{c}{ Chinch bug damage ratings ${ }^{a}$} \\
\cline { 2 - 3 } \cline { 5 - 6 } & \multicolumn{2}{c}{ Study 1} & & \multicolumn{2}{c}{ Study 2} \\
\cline { 2 - 3 } \cline { 5 - 6 } & Infested & Control & & Infested & Control \\
\hline Meyer $^{b}$ & $3.7 \mathrm{a}$ & $1.0 \mathrm{~d}$ & & $3.3 \mathrm{ab}$ & $1.0 \mathrm{c}$ \\
El Toro & $3.0 \mathrm{ab}$ & $1.0 \mathrm{~d}$ & & $3.1 \mathrm{ab}$ & $1.0 \mathrm{c}$ \\
Zorro & $2.5 \mathrm{bc}$ & $1.0 \mathrm{~d}$ & & $2.6 \mathrm{~b}$ & $1.0 \mathrm{c}$ \\
Emerald & $2.2 \mathrm{c}$ & $1.0 \mathrm{~d}$ & & $3.4 \mathrm{a}$ & $1.0 \mathrm{c}$ \\
\hline
\end{tabular}

Means within columns and rows (within the same study) followed by the same letter are not significantly different $(P>0.05$; LSD test).

${ }^{a}$ Chinch damage ratings were based on a $1-5$ scale, where $1, \leq 10 \%$ and $5, \geq 71 \%$ (Heng-Moss et al. 2002).

${ }^{b}$ Susceptible zoysiagrass (Eickhoff et al. 2006).
Table 3. Comparison of $\boldsymbol{B}$. occiduus fecundity on resistant (Presitge) and susceptible (378) buffalograsses (studies 1 and 2)

\begin{tabular}{lcr}
\hline \hline \multirow{2}{*}{ Buffalograss } & \multicolumn{2}{c}{ Mean no. of chinch bugs ${ }^{a}$} \\
\cline { 2 - 3 } & Study 1 & Study 2 \\
\hline Prestige & $40.0 \mathrm{a}$ & $23.0 \mathrm{a}$ \\
PX3-5-1 & $37.2 \mathrm{a}$ & $34.4 \mathrm{a}$ \\
184 & $23.5 \mathrm{a}$ & $20.2 \mathrm{a}$ \\
378 & $17.7 \mathrm{a}$ & $12.7 \mathrm{a}$ \\
196 & $15.5 \mathrm{a}$ & $26.2 \mathrm{a}$ \\
\hline
\end{tabular}

Means within columns (in the same study) followed by the same letter are not significantly different $(P>0.05$; LSD test).

${ }^{a}$ Mean number of chinch bug nymphs (all stages).

significant differences in damage ratings between Meyer and El Toro in either study 1 or 2 or between Meyer and Emerald in study 2. Damage ratings for Emerald zoysiagrass were highly variable (2.2 and 3.4) in these two studies making it difficult to determine its actual level of tolerance. In other studies conducted by Eickhoff et al. (2006), Emerald has displayed high levels of tolerance to B. occiduus. Zorro was the most tolerant zoysiagrass to chinch bug feeding with mean damage ratings of 2.5 and 2.6, respectively. These damage ratings are comparable with those of Prestige, a known chinch bug-resistant buffalograss, indicating Zorro is also tolerant of B. occiduus feeding.

\section{Antibiosis Studies}

Buffalograss Antibiosis Studies 1 and 2. No significant differences (study $1: F=2.0 ; \mathrm{df}=4,27 ; P=0.13$; study $2: F=0.8$; $\mathrm{df}=4,27 ; P=0.57$ ) in the number of chinch bug offspring were detected among the five buffalograss cultivars (Table 3 ). These results indicate the resistant buffalograsses 184, 196, PX3-5-1 and Prestige did not adversely affect chinch bug fecundity rates.

Buffalograss Antibiosis Studies 3 and 4. Significant differences were detected in the nymphal development and survival of $B$. occiduus on resistant and susceptible buffalograsses in studies 3 and 4 (Figs. 1 and 2 ). There were no differences (study $3: F=1.8 ; \mathrm{df}=$ 4,$35 ; P=0.16$; study $4: F=1.2 ; \mathrm{df}=4,35 ; P=0.32$ ) in the number of fourth instars present among buffalograsses in either study 3 or 4 . However, there were significant differences (study $3: F=9.7 ; \mathrm{df}=4,35 ; P=$ 0.0001 ; study $4: F=3.0 ; \mathrm{df}=4,35 ; P=0.03$ ) detected in the number of fifth instars of chinch bugs present in both studies 3 and 4 , with the susceptible buffalograss 378 having significantly higher numbers of fifth instars of chinch bugs present than any of the resistant buffalograsses in study 3 , and significantly more fifth instars than Prestige in study 4 . No significant differences $(F=1.5$; $\mathrm{df}=4,35 ; P=0.23)$ were detected in the number of adults present on the buffalograsses in study 3. However, in study 4, significant differences ( $F=5.2 ; \mathrm{df}=4,35 ; P=0.002)$ were detected, with the resistant buffalograss PX3-5-1 having significantly more adult chinch bugs than all of the other buffalograsses. No significant differences $(F=2.6$; df $=4$, $35 ; P=0.06)$ were detected in chinch bug survival in 


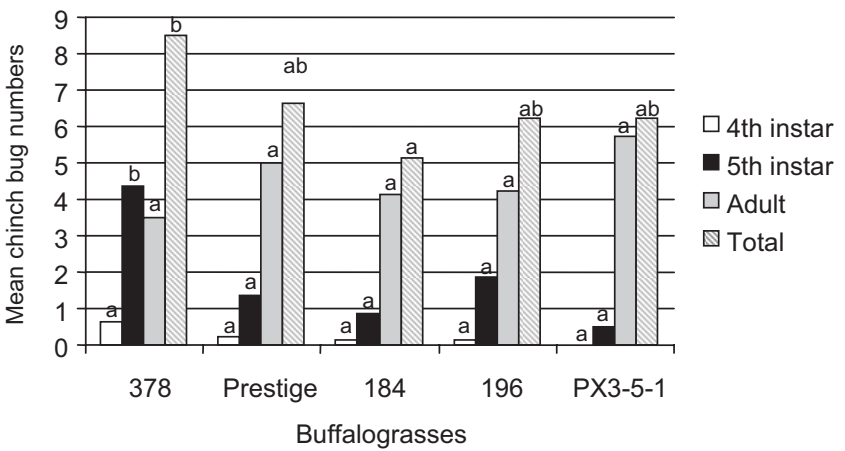

Fig. 1. Nymphal development and survival of B. occiduus on resistant and susceptible (378) buffalograss, study 3. Means within same life stage followed by the same letter are not significantly different $(P>0.05$; LSD test). SE fourth instar, \pm 0.3 ; fifth instar, \pm 0.7 ; adult, \pm 1.0 ; and total, \pm 1.0 .

study 4 . However, significant differences $(F=3.0 ; \mathrm{df}=$ $4,35 ; P=0.03)$ were detected between 378 and 184 in the survival of chinch bugs on the resistant and susceptible buffalograsses in study 3 .

Although significant differences in nymphal development and chinch bug survival were detected in studies 3 and 4, there was little evidence to suggest these resistant grasses are adversely affecting chinch bug development and survival. Relative to nymphal development, 378 had more fifth instars of chinch bugs than the other grasses in both studies. In contrast, all of the other grasses had more adults than 378. This suggested a lag in B. occiduus' development on 378 . This delayed development may be due to 378 being highly susceptible to $B$. occiduus, which may not provide a high-quality food source sufficient for normal chinch bug development. The data from the survival studies revealed no significant differences in B. occiduus survival rates in study 4 . In study 3 , however, 378 had the highest chinch bug survival, but it was only significantly different from the resistant buffalograss 184. There were no differences between 378 and Prestige or among Prestige and the other resistant buffalograsses. These studies do not offer any evidence that the resistant buffalograsses are adversely affecting $B$. occiduus survival.
Zoysiagrass Antibiosis Studies 1 and 2. Significant differences were detected in the development of $B$. occiduus on resistant and susceptible zoysiagrasses in study one (Figs. 3 and 4). However, there were no significant differences (study 1: $F=0.9 ; \mathrm{df}=3,28 ; P=$ 0.45 ; study $2: F=2.5 ; \mathrm{df}=3,28 ; P=0.08)$ in $B$. occiduus survival among the zoysiagrasses (Fig. 3 ).

In study 1 , there were no significant differences detected in the number of third instars $(F=1.0 ; \mathrm{df}=$ $3,28 ; P=0.43)$, fifth instars $(F=0.1 ; \mathrm{df}=3,28 ; P=$ $0.93)$, or adults $(F=2.5 ; \mathrm{df}=3,28 ; P=0.08)$. However, significant differences in the number of fourth instars $(F=3.14 ; \mathrm{df}=3,28 ; P=0.04)$ were detected in study 1 . There were no significant differences among the zoysiagrasses at any life stage in study 2 (third instar: $F=1.8 ; \mathrm{df}=3,28 ; P=0.17$; fourth instar: $F=0.5 ; \mathrm{df}=$ 3,$28 ; P=0.69$; fifth instar: $F=0.5 ; \mathrm{df}=3,28 ; P=0.68$; adults: $F=1.4 ; \mathrm{df}=3,28 ; P=0.28$ ) (Fig. 4 ).

Similar to the buffalograsses, there were few significant differences in nymphal development, and no significant differences in chinch bug survival among the zoysiagrasses in studies 1 and 2. Again, the results of these studies provide little evidence to suggest that these resistant grasses are adversely affecting chinch bug development or survival. The only significant differences detected among the zoysiagrasses were in

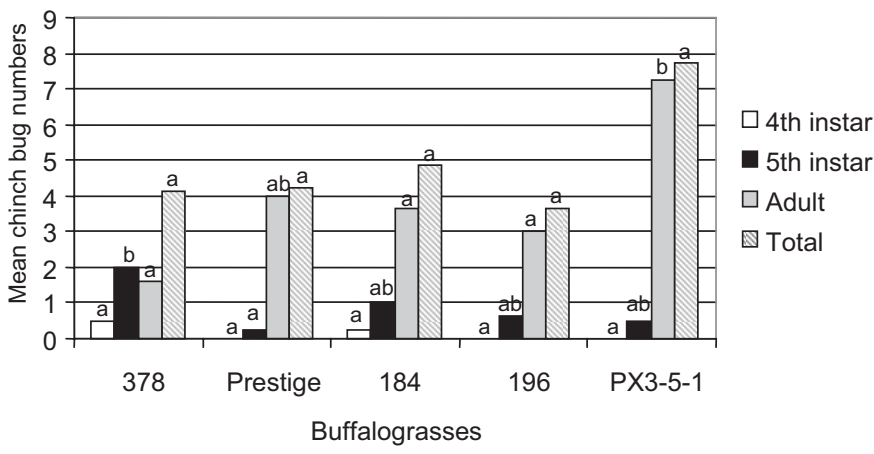

Fig. 2. Nymphal development and survival of B. occiduus on resistant and susceptible (378) buffalograss, study 4. Means within same life stage followed by the same letter are not significantly different $(P>0.05$; LSD test). SE fourth instar, \pm 0.3 ; fifth instar, \pm 0.6 ; adult, \pm 0.9 ; and total, \pm 1 .3. 


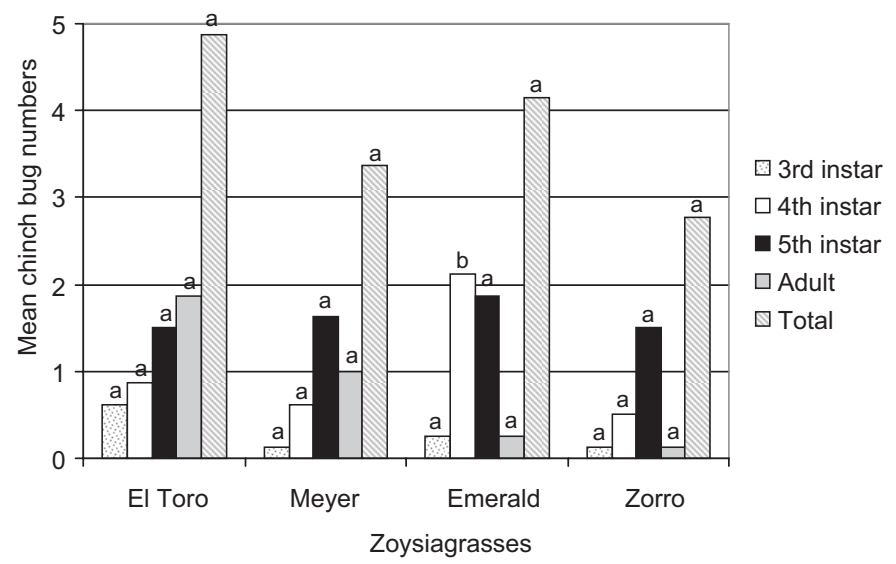

Fig. 3. Nymphal development and survival of B. occiduus on resistant and susceptible (Meyer) zoysiagrass, study 1. Means within same life stage followed by the same letter are not significantly different $(P>0.05$; LSD test). SE third instar, \pm 0.3 ; fourth instar, \pm 0.6 ; fifth instar, \pm 0.7 ; adult, \pm 0.5 ; and total, \pm 1.1 .

study 1; where Emerald had significantly more fourth instars (2.1) than either Zorro, El Toro, or Meyer (0.9, 0.6 , and 0.5 , respectively). These studies do not provide convincing evidence that the resistant zoysiagrasses are affecting B. occiduus survival.

\section{Antixenosis Studies}

Buffalograss Antixenosis Studies. Mixed model analysis detected no significant differences $(P>0.05)$ between the antixenosis studies so the data were pooled. Significant differences in chinch bug preference were observed among the buffalograsses $(F=$ 2.7; $\mathrm{df}=4,76 ; P>0.03$ ) (Fig. 5). The buffalograss 86-120 was consistently the most preferred cultivar (except at $8 \mathrm{~h}$ after introduction) of the grasses tested which supports the findings of Heng-Moss et al. (2003). The greatest difference in chinch bug numbers occurred between 86-120 and 196 at $24 \mathrm{~h}$ when 86-120 had $>4$ times as many chinch bugs present. 86-120 had significantly more chinch bugs than the resistant buffalograss Prestige at all times except for $4 \mathrm{~h}$ after introduction. 86-120 also had significantly more

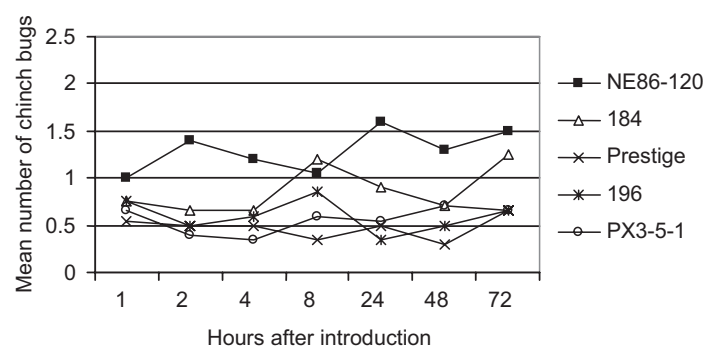

Fig. 4. Nymphal development and survival of B. occiduus on resistant and susceptible (Meyer) zoysiagrass, study 2. Means within same life stage followed by the same letter are not significantly different $(P>0.05$; LSD test). SE third instar, \pm 0.3 ; fourth instar, \pm 0.7 ; fifth instar, \pm 0.6 ; adult, \pm 0.3 ; and total, \pm 1.0 . chinch bugs than 196 at all times (except 4 and $8 \mathrm{~h}$ after introduction), and PX3-5-1 (except for 8 and $48 \mathrm{~h}$ after introduction). The buffalograsses Prestige, PX3-5-1 and 196 were the least preferred of all the buffalograsses throughout the study, and they did not have statistically significant differences in chinch bug numbers at any time. The buffalograss 184 was the second most preferred grass at all times except for $8 \mathrm{~h}$ after chinch bug introduction when it was the most preferred. The buffalograss 184 was not significantly different from any of the other grasses tested except at $2 \mathrm{~h}$ after introduction, when it had significantly fewer chinch bugs than 86-120. The buffalograss 184 also had significantly more chinch bugs than Prestige at $8 \mathrm{~h}$ after introduction. Results of this study indicates that B. occiduus prefers 86-120 to Prestige, PX3-5-1 and 196. Furthermore, the data suggests 196 has comparable levels of antixenosis as Prestige.

Zoysiagrass Antixenosis Study. Mixed model analysis detected no significant differences $(P>0.05)$ between the antixenosis studies so the data were pooled. A significant interaction between zoysiagrass treatment and time $(F=2.38 ; \mathrm{df}=18,456 ; P>0.0012)$ was detected (Fig. 6). There were no significant differences among the zoysiagrasses tested at 1, 4, 48, and $72 \mathrm{~h}$ after chinch bug introduction. At $2 \mathrm{~h}$ after introduction, Zorro had significantly more chinch bugs than Emerald. However, this number was not statistically different from either El Toro or Meyer. The greatest differences in chinch bug preference occurred between El Toro and Emerald at 8 and $24 \mathrm{~h}$ ( 1.35 to 0.35 and 1.95 to 0.75 chinch bugs, respectively) after introduction. At $8 \mathrm{~h}$ after introduction there were significantly more chinch bugs on El Toro than on Emerald, but there was no difference between El Toro, Zorro, and Meyer, or Emerald, Zorro and Meyer. By $24 \mathrm{~h}$, El Toro had significantly more chinch bugs than all other zoysiagrasses.

This study indicates that the zoysiagrass El Toro is highly preferred by B. occiduus, and Emerald may 


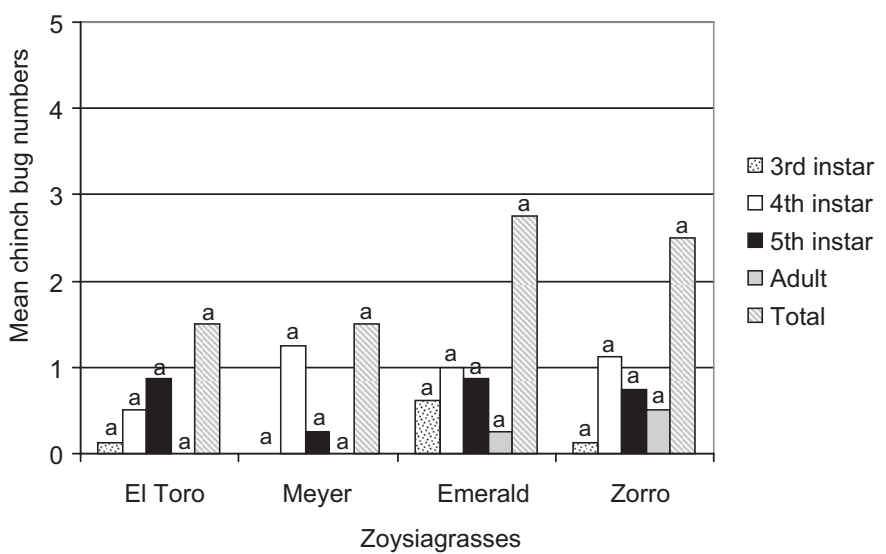

Fig. 5. Comparison of B. occiduus preference for selected buffalograsses. SE, \pm 0.04 .

have low levels of antixenosis. It is noteworthy that there was a decline (1.95 to 0.8 ) in the number of chinch bugs on the highly preferred zoysiagrass El Toro and an increase $(0.2-0.9)$ on the less preferred zoysiagrass Emerald between 24 and $48 \mathrm{~h}$ after introduction. These changes likely reflect a decline in El Toro quality, forcing the chinch bugs to seek a more favorable host.

This research categorized the resistance of several buffalograsses and zoysiagrasses to chinch bug feeding by assessing levels of antibiosis, antixenosis and tolerance. The buffalograsses 184 and PX3-5-1 were characterized as tolerant, whereas, 196 showed both tolerance and antixenosis. Among the zoysiagrasses, Zorro was tolerant to B. occiduus feeding, whereas Emerald displayed tolerance with possible low levels of antixenosis.

This study is the first to categorize the resistance of zoysiagrass to $B$. occiduus, and it provides further insight into resistance among buffalograsses. The information generated from this research raises questions regarding the plant's defense responses to insect feeding, and why some grasses are better able to tolerate insect feeding than other cultivars of the same species. Tolerance responses may be the result of physiological or biochemical responses such as increased photosynthetic capacity, nutrient uptake, or oxidative enzyme activity (Kessler and Baldwin 2002, Heng-Moss et al. 2004). The identification of mechanisms responsible

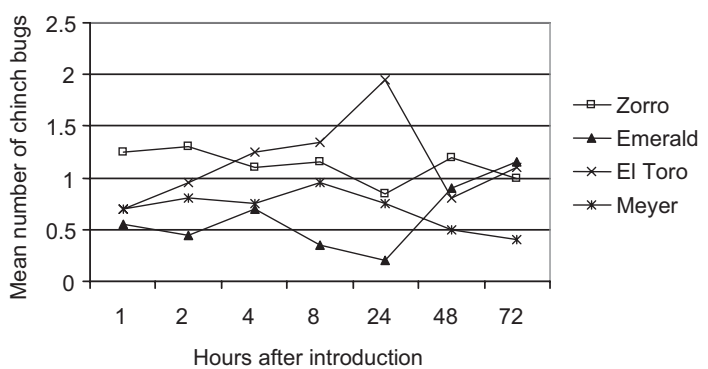

Fig. 6. Comparison of B. occiduus preference for selected zoysiagrasses. $\mathrm{SE}, \pm 0.30$. for the tolerance will aid in our understanding of plant-insect interactions, the defense responses of plants and should be a focus of future research.

The identification of tolerant grasses also has important implications on the management of turfgrass pests, and the preservation of resistance. Unlike antibiosis and antixenosis, tolerance does not apply undue selection pressure on pest populations. By limiting selection pressure, the durability of the plant resistance is improved. Therefore, the identification and use of insect-tolerant grasses can have a large impact on our chinch bug management program. Furthermore, this research underscores the need to identify the underlying mechanisms of resistance among these tolerant grasses to further our understanding of how these plants are defending themselves from insect pests and whether we can incorporate these traits into other plant systems. Future research should continue to focus on the categorization of insect-resistant plants, and investigations into the underlying mechanisms of this resistance.

\section{Acknowledgments}

We gratefully acknowledge J. Wagnitz, W. Anderson, M. Stamm, C. Wasem and L. Toda (University of Nebraska) for technical assistance. This research was supported in part by the University of Nebraska Agricultural Experiment Station Project NEB-17-062 and 17-078, the United States Golf Association and the Nebraska Turfgrass Association.

\section{References Cited}

Ahmad, T. R., J. M. Johnson-Cicalese, W. K. Dickson, and C. R. Funk. 1986. Endophyte enhanced resistance in perennial ryegrass to the bluegrass billbug, Sphenophorus parvulus. Entomol. Exp. Appl. 41: 3-10.

Baker, P. B., R. H. Ratcliffe, and A. L. Steinhauer. 1981. Tolerance to hairy chinch bug (Blissus leucopterus) feeding in Kentucky bluegrass (Poa pratensis). Environ. Entomol. 10: 153-157.

Baxendale, F. P., T. M. Heng-Moss, and T. P. Riordan. 1999. Blissus occiduus (Hemiptera: Lygaeidae): a chinch bug pest new to buffalograss turf. J. Econ. Entomol. 92: 11721176. 
Braman, S. K., A. F. Pendley, R. N. Carrow, and M. C. Engelke. 1994. Potential resistance in zoysiagrasses to tawny mole crickets (Orthoptera: Gryllotalpidae). Fla. Entomol. 77: 301-305.

Eickhoff, T. E., T. M. Heng-Moss, and F. Baxendale. 2006. Evaluation of warm-season turfgrasses for resistance to the chinch bug, Blissus occiduus. HortScience 42(3): $718-720$.

Eickhoff, T. E., F. P. Baxendale, T. M. Heng-Moss, and E. E. Blankenship. 2004. Turfgrass, crop and weed hosts Blissus occiduus (Hemiptera: Lygaeidae). J. Econ. Entomol. 97: $67-73$.

Gulsen, O., T. M. Heng-Moss, R. Shearman, P. S. Baenziger, D. Lee, and F. P. Baxendale. 2004. Buffalograss germplasm resistance to Blissus occiduus (Hemiptera: Lygaeidae). J. Econ. Entomol. 96: 2101-2105.

Heng-Moss, T. M., F. P. Baxendale, T. P. Riordan, and J. E. Foster. 2002. Evaluation of buffalograss germplasm for resistance to Blissus occiduus turf. J. Econ. Entomol. 95: 1054-1058.

Heng-Moss, T. M., F. P. Baxendale, T. P. Riordan, L. J. Young, and K. Lee. 2003. Chinch bug-resistant buffalograss: an investigation of tolerance, antixenosis and antibiosis. J. Econ. Entomol. 96: 1942-1951.

Heng-Moss, T. M., G. Sarath, F. P. Baxendale, D. Novak, S. Bose, X. Ni, and S. Quisenberry. 2004. Characterization of oxidative enzyme changes in buffalograsses challendged by Blissus occiduus. J. Econ. Entomol. 97: 10861095.

Heng-Moss, T. M., T. Macedo, L. Franzen, F. P. Baxendale, L. Higley, and G. Sarath. 2006. Physiological responses of resistant and susceptible buffalograsses to Blissus occiduus (Hempitera: Blissidae) feeding. J. Econ. Entomol. 99: 222-228.

Johnson-Cicalese, J. M., R. H. Hurley, G. W. Wolfe, and C. R. Funk. 1989. Developing turfgrasses with improved resistance to billbugs, pp. 107-111. In 6th International Turfgrass Research Conference, 31 July-5 Aug. 5, Tokyo,
Japan. Japanese Society of Turfgrass Science, Tokyo, Japan.

Johnson-Cicalese, J. M., F. P. Baxendale, T. P. Riordan, and T. M. Heng-Moss. 1998. Identification of mealybug(Homoptera: Pseudococcidae) resistant turf-type buffalograss germplasm. J. Econ. Entomol. 91: 340-346.

Kessler, A., and I. T. Baldwin. 2002. Plant responses to insect herbivory: the emerging molecular analysis. Annu. Rev. Plant Biol. 53: 299-328.

Littell, R. C., A. Millicken, W. W. Stroup, and R. D. Wolfinger. 1996. SAS system for mixed model. SAS Institute, Cary, NC.

Quisenberry, S.S. 1990. Plant resistance to insects and mites in forage and turfgrasses. Fla. Entomol. 73: 411-421.

Rangasamy, M., H. J. McAuslane, R. H. Cherry, and R. T. Nagata. 2006. Categories of resistance in St. Augustinegrass lines to southern chinch bug (Hemiptera: Blissidae). J. Econ. Entomol. 99: 1446-1451.

Reinert, J. A. 1982. A review of host resistance in turfgrasses to insects and Acarines with emphasis on the southern chinch bug, pp. 3-12. In H. D. Niemczyk and B. G. Joyner [eds.], Advances in turfgrass entomology. Hammer Graphics, Inc., Piqua, OH.

Reinert, J. A., and P. Busey. 2001. host resistance to tawny mole cricket, Scapteriscus vicinus, in bermudagrasss, Cynodon spp. Int. Turfgass Soc. Res. J. 9: 793-797.

SAS Institute. 2002. SAS/STAT software changes and enhancements through release 9.1. SAS Institute, Cary, NC.

Smith, C. M. 1989. Plant resistance to insects. Wiley, New York.

Smith, C. M., Z. R. Khan, and M. D. Pathak. 1994. Techniques for evaluating insect resistance in crop plants. Lewis Publishers, Boca Raton, FL.

Southwood, T.R.E. 1978. Ecological methods. Halstad, New York.

Received 16 March 2007; accepted 8 October 2007. 